Sigurd Høye (f. 1972) er assisterende medisinsk redaktør i Tidsskriftet og forsker ved Antibiotikasenteret for primærmedisin, Avdeling for allmennmedisin, Universitetet i Oslo. Hans doktoravhandling fra 2013 omhandlet vent-og-se-resept.

\section{Ikke spør legen}

«Ask your doctor!» gjentas til det kjedsommelige i TV-reklamer for reseptbelagte legemidler, i land der slikt er tillatt (1). Hensikten er å påvirke potensielle pasienter til å oppsøke legen. Det kan virke tilforlatelig, det er jo aldri galt å gå til legen. Eller?

Den viktigste risikofaktoren for å bli utsatt for overdiagnostisering og overbehandling er å oppsøke helsevesenet. Eller, anvendt på det området jeg kjenner best: Den viktigste risikofaktoren for å få en unødvendig antibiotikaresept er å gå til legen.

I Norge er vi vant til å tenke at leger er restriktive forskrivere og at dette forklarer landets relativt lave antibiotikabruk og dermed vårt forholdsvis begrensede problem med resistente mikrober. Det er en viss sannhet i dette, men det er likevel kun en del av forklaringen. Allmennleger forskriver fortsatt antibiotika i tre av fire konsultasjoner for akutt sinusitt og i tre av fem konsultasjoner for akutt bronkitt (2). Tilsvarende andel ved akutt bronkitt i sør- og østeuropeiske land er gjerne fire av fem (3). Denne lille forskjellen forklarer ikke hvorfor antibiotikabruken i disse landene er 2-3 ganger høyere enn i Norge (4).

Etter en bekymringsverdig økning sank antibiotikaforskrivningen i britisk allmennpraksis ganske betydelig $i$ andre halvdel av 1990årene (5). Det er lett å tolke dette som at allmennlegene ble mer restriktive. Ved nærmere ettersyn viste det seg at befolkningen hadde mesteparten av æren for reduksjonen: Legenes forskrivningsrate ved luftveisinfeksjoner sank med $15 \%$, mens befolkningens konsultasjonsrate for luftveisinfeksjoner sank med hele $35 \%$ (5).

Primærhelsetjenesten har sitt eget sykdomspanorama, som er temmelig forskjellig fra annenlinjetjenestens panorama. Dette er en av årsakene til at kunnskap fra sykehusbasert forskning ikke nødvendigvis kan overføres til allmennpraksis. Vi må imidlertid ikke glemme at det allmennmedisinske sykdomspanoramaet heller ikke tilsvarer det faktiske sykdomsbildet i befolkningen. Primærhelsetjenesten siler pasienter for annenlinjetjenesten, men den groveste silingen skjer ikke på allmennlegekontoret. Den skjer i hjemmene.

Hva er det så som bestemmer befolkningens legesøkning? Forfatterne av den britiske studien mener forklaringen på det betydelige fallet i legesøkning var en økende bevissthet om at egenomsorg var å foretrekke fremfor legebesøk (5). Hva den økende bevisstheten skyldtes, er vanskelig å si. Pasientrettede kampanjer om fornuftig antibiotikabruk ble satt i gang i omtrent samme tidsrom. Legens forskrivningspraksis vil også påvirke pasientens legesøkning: Hvis pasienter med sår hals får forskrevet antibiotika istedenfor ingen resept eller vent-og-se-resept, vil de i større grad gå til lege igjen neste gang de får sår hals (6). Det er også vist at dersom foreldre får informasjon blant annet om det naturlige, ubehandlede forløpet av en luftveisinfeksjon, vil de i mindre grad ønske å bringe barn til lege for en slik tilstand (7). Svært mange vet ikke at det er helt vanlig - og ikke bekymringsverdig - å hoste i flere uker ved akutt bronkitt.

Å gi et direkte råd om ikke å oppsøke lege er problematisk. Vi vil aldri oppleve at kun dem som med sikkerhet har behov for et aktivt medisinsk tiltak, kommer til lege. Så god blir aldri den hjemlige silingen. Men rådet ble like fullt gitt under influensapandemien i 2009. «Småsyke» ble bedt om å holde seg unna fastlegekontor og legevakt (8). I pandemiperioden sank også kontaktraten for blant annet akutt otitt og akutt sinusitt på legevakt med rundt $30 \%$ sammenliknet med de tre foregående årene (9), og antibiotikabruken i 2009 var $4 \%$ lavere enn året før (10). Bedret hygiene som følge av myndighetenes rådgivning ble vurdert å kunne forklare hvorfor færre gikk til lege (9). En vel så sannsynlig hypotese er at folk faktisk fulgte rådet om ikke å oppsøke helsevesenet.

Sykehuslegen må ha allmennmedisinens sykdomspanorama in mente. Men allmennlegen må også være bevisst det totalt uselekterte sykdomsbildet: Hva er det som gjør at akkurat denne personen velger å bli pasient? Ved å gi god informasjon og unngå unødvendige tiltak kan den hjemlige silingen bli enda bedre.

Litteratur

1. Ask your doctor. Youtube.com 2009. www.youtube.com/watch?v=KDarqCVXUoQ (2.7.2014)

2. Gjelstad S, Straand J, Dalen I et al. Do general practitioners' consultation rates influence their prescribing patterns of antibiotics for acute respiratory tract infections? J Antimicrob Chemother 2011; 66: 2425-33.

3. Butler CC, Hood K, Verheij T et al. Variation in antibiotic prescribing and its impact on recovery in patients with acute cough in primary care: prospective study in 13 countries. BMJ 2009; 338: b2242.

4. Adriaenssens N, Coenen S, Versporten A et al. European Surveillance of Antimicrobial Consumption (ESAC): outpatient antibiotic use in Europe (1997-2009) J Antimicrob Chemother 2011; 66 (suppl 6): vi3-12.

5. Ashworth M, Latinovic R, Charlton J et al. Why has antibiotic prescribing for respiratory illness declined in primary care? A longitudinal study using the General Practice Research Database. J Public Health (Oxf) 2004; 26: 268-74.

6. Little P. Gould C, Williamson I et al. Reattendance and complications in a randomised trial of prescribing strategies for sore throat: the medicalising effect of prescribing antibiotics. BMJ 1997; 315: 350-2

7. Francis NA, Butler CC, Hood K et al. Effect of using an interactive booklet about childhood respiratory tract infections in primary care consultations on reconsulting and antibiotic prescribing: a cluster randomised controlled trial. BMJ 2009; 339: b2885.

8. Engh C, Vangerud L. Fastlegene og Legevakten ber småsyke holde seg hjemme. Aftenposten Aften 22.10.2009

9. Sandvik H, Hunskår S. Hygienekampanjen høsten 2009 - færre infeksjonstilfeller på legevakt? Tidsskr Nor Legeforen 2011; 131: 680-3.

10. NORM/NORM-VET 2009. Usage of antimicrobial agents and occurrence of antimicrobial resistance in Norway. Tromsø/Oslo: NORM/NORM-VET, 2010. 